\title{
The Social Support Network for Rural Migrant Workers in Chengdu, China: Local Governance and Civil Society in the Fight Against Poverty and Exclusion
}

\author{
Ming Zhuang
}

\begin{abstract}
The rights and social security of rural migrant workers have been addressed in China in recent years as a result of the work of government departments, international agencies and civil society organisations. This case study of the Social Support Network for Rural Migrant Workers in Chengdu, capital of Sichuan Province, explores one such initiative, in a context in which civil society must operate within the framework of explicit political authorisation and official guidance. The case discusses how well-placed civil society actors were able to create a space for migrant workers' concerns, which included private sector service providers and the media as well as local government officials. Channels for communication, consultation and advocacy around migrant workers' rights have catalysed some important gains in the regime of service delivery for rural migrant workers.
\end{abstract}

\section{Introduction \\ 1.1 The context \\ In the last 30 years and under the broad policy of open reform, China has experienced many of the dramatic changes typical of developing countries, including polarisation of the social system and segregation. In this process, rural migrant workers have become China's largest disadvantaged group, working under poor conditions with meagre salaries, no medical insurance, and no decent work injury compensations. Migrant workers typically lack rights to vote or to participate in urban community life, and have to pay to educate their children, as urban public schools are not required to accept them because they are generally registered back in their rural communities of origin.}

In recent years, the rights and social security of rural migrant workers have begun to improve as a result of the work of government departments, international agencies and civil society organisations. This case study explores one such initiative. A key feature of the interaction between civil society and government in China is that it is only within the framework of explicit political authorisation and guidance from the government that civil society can engage in and build mechanisms to tackle exclusion and reduce poverty. This suggests that, compared with other countries, civil society may be less autonomous in its efforts to promote social or political development than elsewhere. However, recent experiences indicate that civil society organisational initiatives can not only provide opportunities for public participation and advocacy in favour of the disadvantaged, but can also provide local and central governments with potential solutions and even pilot versions of public services. This study looks at the work of the Social Support Network for Rural Migrant Workers in Chengdu, a major city in Western China and capital of Sichuan Province, where over one-fifth of the population are rural migrant workers and their families. This case focuses on three key concerns: labour rights, children's education and social security. It shows how joint civil society and government initiatives to reverse 
the patterns of migrant workers' exclusion from these public services came about and their achievements and continuing challenges.

\subsection{A society in transition: civil and political society in China}

China is very much a society in transition, and awareness of the importance of citizen participation is growing. In addition to the formal mechanisms of elections and consultative party conferences, there are many different national political associations among which are the Workers Union, Youth League, Women's Federation, Literature Association, Journalists Association and the Social Sciences Association. Grass roots organisations also exist at the neighbourhood level and include village committees in rural areas and their equivalent in the towns and cities. In addition, there are also Ombudsman offices, hotlines and websites, which can also work as channels of communication.

While experts and scholars as well as the media have used these openings, community level organisation has been less present. Nongovernmental organisations (NGOs) are a recent phenomenon, with a history of about ten years since the Open Policy. The tendency is to regard NGOs as all independent, non-profit, autonomous, voluntary and philanthropy organisations, including service providers other than the government system. NGOs have always maintained a delicate relationship with government, given that they explicitly exist within a social space assigned by the government and their relationship with government is not one of independent cooperation, but one of dependence. At the same time as their activities and approaches are closely tied with the government's assigned space, they are a voice on citizen rights, concerned with the social commonwealth and seeking ways of enhancing 'society coordination and public participation' in social public affairs. Economic elites, represented by private entrepreneurs also can be found in the political arena, but they mainly organise questions of direct concern rather than any broader philanthropic action (Yu 2009).

\subsection{From rural to urban}

With the establishment of the People's Republic of China in 1949, economic development favoured heavy industry in a capital centralisation process that would continue into the 1950s. Capital (including labour) was allocated on a region-industry-proprietorship basis, with policies and systems limiting the mobility of resources within and between them. Among the systems brought in was household registration, which typically separated urban and rural labour, along with such auxiliary systems as urban employment, the social welfare security system, the ration-coupon system for food supply and exclusive social welfare systems, which impeded the mobility of the labour between regions and departments. With the rural and urban populations entitled to different social welfare and security and the largest part of the welfare resources going to the urban areas, the result was a dual structure of society into urban and rural with different social administration mechanisms and systems for each (Zhan 2005).

Despite these separate systems and the corresponding disincentives, from the late $1970 \mathrm{~s}$ and early 1980s onwards other factors stimulated a move to the towns. Overall reform and open market economic development on the one hand and tighter controls on production and remuneration in the rural areas on the other, saw a significant number of the rural surplus labour force moving into the cities and towns as rural migrant workers. However, given their rural status within the separate welfare and security structures, they were not entitled to labour rights or to welfare and other services such as social insurance, medical and healthcare, education for their children, care and housing for the elderly. As a result and within the dualistic model of the household registration system, they became discriminated against and excluded both by the labour market and urban society (Zhan 2005).

Even though the years of reform have introduced anti-poverty programmes, China's economic development gap between urban and rural areas has grown, and socioeconomic inequality increased (Ravallion and Chen 2004). In 1986, the Central Government set up the Anti-poverty and Development Office, subordinated to the State Council and specialised in rural antipoverty issues and similar institutions were set up in poor areas at province, city and county level. However, despite their rural focus, the policies made at this early stage ignored the great number of rural migrant workers that had 
appeared after the market reforms. Although they lived and worked in urban areas, they were, for registration purposes, an agricultural population, and as such, neither entitled to the benefits of anti-poverty polices for rural areas, nor to those for urban areas. They were caught in a policy gap (Huang 2004).

Since 2000, there have been a number of changes with important government policy documents both for protecting rural migrant workers' rights and welfare, as well as encouraging rural labour migration. Among these were the State Council General Office documents 'Notice on Employment Administration and Service Works for Farm Workers in Urban Areas'1 and 'Opinions on Solving Several Problems of Rural Migrant Workers'2 published, respectively in 2003 and 2006, which set out safeguards for rural migrant workers' rights and interests.

There remain gaps and difficulties with respect to migrant workers' access to labour protection, medical care and education, as well as participation in urban governance. In accordance with household registration and voting principles, rural migrant workers who reside in urban destination areas cannot participate in the local voting and community autonomy actions. Thus among about 3,000 National People's Congress members, there are only three rural farmer representatives, and these attended for the first time the 11th Congress in 2008. Given that it is estimated that the rural migrant worker population is some 10 per cent of the entire Chinese population, this level of representation is limited. In Qingyang District in Chengdu, the urban focus of the case study, it was only in 2007 that the first rural migrant worker was elected as Community Deputy Secretary of the Communist Party.

\section{The Social Support Network for Rural Migrant Workers}

\subsection{The origins of the Network}

The Social Support Network for Rural Migrant Workers grew out of initial activities and studies in the late 1990s into the conditions of migrant workers, which featured special attention to migrant women. This led to two centres for migrant women being set up in the region, one in Jintang County and the other in Chengdu by the Jintang County Women's Federation and the Sichuan Prefecture Women's Federation. The work proceeded slowly with little local government support, until it was included along with seven other Chinese sites within the 'East Asia Anti-poverty Program for Young Immigrants' financed by the United Nations Educational, Scientific and Cultural Organisation (UNESCO). Among the factors that drove this support was a 2002 study showing that while the work of the centres was important for skill training, many aspects of urban life that are taken for granted by city dwellers had no part of the rural life experience, such as street lights and traffic, domestic appliances and modern healthcare services; lack of familiarity with which could lead to discrimination and exclusion from domestic work.

The aims of the programme were to improve the activities of the two centres and to build a broader network of different actors able to engage government actors in order to generate effective policies for protection and promotion of conditions for migrant workers, which would in turn lead to less discrimination (UNESCO 2007: 99-100). The programme lasted for about five years, from planning and assessment in 2002, implementation from 2003, and completion and evaluation in $2007 .{ }^{3}$

Sichuan Province is a heavily populated province in the less-developed mid-west of China. ${ }^{4}$ Chengdu, as the capital of Sichuan as well as a major city in its own right, attracts migrant workers from Sichuan Province and from other provinces. With an official population of more than 10 million people, the officially registered migrant population of Chengdu was about 800,000 in 2002, and 2.16 million in 2008. ${ }^{5}$ Given the results of other population studies, this is probably an underestimate, as many migrant workers do not register. Some suggest that the difference can be as high as 300 per cent.

The Sichuan Women's Federation and the Sichuan Academy of Science led the programme from the outset. Although the two organisations are part of state-owned institutions, they are not part of government line departments. The programme was conceived as a research and service network that would reach out to organisations in many different spheres; as it evolved and participation in the network grew, so did the attitudes of government actors begin to shift. Support was provided both by UNESCO 
and by network participants, who also contributed their own specific resources.

At first, the Program Task Force consisted of a number of experts and scholars, aided by NGOs, rural migrant activists and volunteers. With the development of the programme, network members recognised the importance of increasing cooperation with government, media, business corporations, schools and lawyers, both to support problem-solving and for further mobilisation. The network played an active role in promoting public and government awareness of rural migrant workers' rights and interests within Chengdu and the province. Through an increase in direct training, rights protection, help-lines, newspaper communication, volunteers' activities, as well as indirect cooperation with private sectors, impacts began to be felt on migrant workers' income levels, educational service access and social security provision. More importantly, through the programme, resources from other governments and non-governmental actors were mobilised to support anti-poverty and exclusion for rural migrant workers (Merklen 2007).

This was also the period in which, stimulated by central government, regional and local governments also began to discuss the improvement of farm workers' rights and interests, and to promote anti-poverty and exclusion for rural migrant workers. This in turn led to a shift in local government orientation, from administrative control to service provision. The conjuncture of shifts in national policy and local government orientations with the existing interactions and mutual influences among local citizens and social organisations, formed a new arena of interaction and collaboration between state, civil society and local stakeholders at the local level:

The 'network' was composed of NGOs (like the Chengdu Women's Federation), researchers (from Sichuan University, Sichuan Academy of Social sciences and Chengdu Academy of Social Sciences), private sector (Chuanmeizi Domestic Wroker Company), street and community operators (Jinniu Street Committee, Shuanghe Street Committee), media (Sichuan Daily, Chengdu evening and others), volunteers (lawyers, students and migrants themselves), and also some officials from Chengdu Education, Health, Legal and Civil Affairs Bureaus. (UNESCO 2007: 100)

\subsection{Actors and interactions}

Five groups of actors can be usefully distinguished in the Network: government, civil society, the private sector, the media and the migrant workers themselves. Within China's political and institutional model, central government formulates nationwide policies, mobilises resources and requires implementation by local governments. Under the one party system, government departments at all levels are under the leadership of the corresponding levels of the party committee structure. We use the term 'government' here to refer to government departments and party organisations at all levels, from central to local. Key to the Network's activities were the local education bureau, the bureau of labour and social security, the subdistrict government offices, healthcare and family planning administration bureaux. The local education bureau is in charge of provision and administration of compulsory education for rural migrant workers' children, the bureau of labour and social insurance is mandated to protect migrant workers' labour rights and to provide skills training and social security; as the lowest tier of urban local government, the sub-district office is in charge of administrative functions such as migrant registration, child immunisation, family planning and labour rights protection.

Also important in relationship to government are processes of centralisation and decentralisation, including the recent reform of the financial system, which has offered some local governments relative financial autonomy with respect to expenditure. Nevertheless, China's power system remains centrally controlled, with policies sent down to local governments for implementation. In this context, civil society has to be used loosely to refer to such nongovernment and non-private forces as Sichuan Academy of Social Sciences, Sichuan Women's Federation, Party School of CPC Sichuan Province Committee, volunteers, international institutions and the programme donor UNESCO. The Women's Federation is an official NGO having a complete structure from central authorities to organisations at provincial, municipal and township levels. The Academy of Social Sciences is a state-owned institution, a think tank for local government as well as an 
academic research institute of social sciences. In China, academies of the social sciences are established in each province and capital city, including a nationwide one at the central. Although these organisations have party and governmental duties, they enjoy a degree of independence in that they can advocate for change, carry out training activities and engage in multilateral dialogue.

Civil society organisations within the Network have played an enduring role in advocacy and protection of rural migrant workers' rights and welfare, but their capacity for direct influence on the government is limited. In the case of the Network, UNESCO also played an important role through its contacts with central government departments.

However, one question the present case gives rise to is that of the relevance of discussions of participatory governance, citizens and civil society in the China context. The experience with 'civil society' involvement in the widening space for migrant workers' participation and rights in Chengdu fits uneasily within a de Tocquevillean concept of civil society as the organisation of public social life, within the law yet autonomous from government; this is not the pattern of 'civil society' action as seen in this Chinese context. ${ }^{6}$

Yet the success of the Network and the way in which it has opened up issues, taking advantage of new government initiatives, while also stimulating these, show that 'civil society' organisations do enjoy a relative autonomy in creating spaces for both service provision and advocacy. At the same time, connectedness to government endows 'civil society' with considerable power and authority. For example, by virtue of their own government background and professional knowledge, the Women's Federation and Academy of Social Sciences succeeded in amplifying the voice of rural migrant workers in official spaces.

The private sector members of the Network were private for-profit providers of services that rural migrant workers require, such as primary schools especially established for rural migrants' children, skills training, job centres and law firms. Under Chinese law, children must receive nine years of compulsory education and when such services are not provided publicly, private providers emerge to meet this demand. But as owners of private schools for migrant workers' children tend to be profit-motivated, there are often concerns with low teaching quality, lack of space, equipment and security. Nevertheless, private schools remain part of the solution for primary education provision for migrant workers' children in the cities. The private education sector has a mixed subordinate status, actively striving for resources and support from rural migrant workers, civil society organisations and governments when providing public services, while also striving for survival under government regulation and constraints. They frequently struggle to maintain a lukewarm relationship with government actors.

Among the private sector actors within the Network are labour contracting service companies, which train migrant workers to fulfil labour contracts, and which also offer some rights protection and support. Law firms also provide support, but their main work is in the area of wage claims and injury compensation. However, legal proceedings are difficult and the rewards for the law firms are low with the result that neither the workers nor the firms see this as a productive relationship, despite the fact that government requires law firms to contribute voluntary time and effort for the disadvantaged.

The media includes local newspapers, magazines and television stations. At all levels the media is active, particularly on 'hot' social topics such as rural migrant workers' rights. But as the voice of the party and government, the media is also consistent and generally follows government lines. In this case, the government policy documents on anti-poverty and anti-exclusion for migrant workers led to media monitoring of events by local media, organising communications among party committees and assisting government in hearing the views of excluded people and civil society.

The last group of actors in the Network are the rural migrant workers, defined as people registered as a rural household but who work and live in towns. At the early stages of migration, they faced multiple discriminations and exclusions, but reforms are improving their rights. Their own participation in anti-exclusion and anti-poverty actions is often difficult due to a 
lack of efficient channels and mechanisms for participation. As noted above, civil society has a particularly important role to play in a context in which autonomy from government can mean illegality or irrelevance. A singular success of the Network has been its capacity to amplify the voice of migrant workers, whose exclusion from participation in the past has forced them to resort to direct action. This has included a wide range of 'uncivil' actions, including jumping off buildings in protest against the lack of rights protection, or involvement in direct violent conflict with government. Other strategies have included making use of media, civil society organisations, and even governmental actors in an attempt to influence official conduct and decision-making around migrant workers' rights.

\section{The Rural Migrant Work Social Support Network in action}

Important for the success of the Rural Migrant Worker Social Support Network has been the many links established with and between the different actors, stakeholders, relevant government departments and institutions attached to or sponsored by government, such as the Labour and Social Security Bureau of Chengdu, Education Bureau of Chengdu, Southern Railway Station Sub-district Office, West Xinhua Road Sub-district Office, Party School of CPC Sichuan Province Committee, Communist Youth League School of Chengdu, and Chengdu Municipal Centre for Disease Control and Prevention amongst others; with the civil society organisations, research institutions such as Sichuan Academy of Social Sciences, Sichuan Women's Federation, Women's Federation in Jintang county, which is a major starting point for migrant workers; local NGOs, Blue Light Intellectual workshop, local universities volunteers; local media such as Sichuan Daily Press, Chengdu Business Daily Press; relevant private business and service institutions such as Yangfan School, Bashu School, Dushi School, Zhiyuan School, Anwei Household Service Company and Dingli Law Firm. Meetings are held among network members, and the network edits newsletters to both mobilise resources and help communication between the different groups of actors.

\subsection{Communication}

Improved communication has led to a number of gains. For example, the schools for migrant workers' children and the household service contracting companies were in financial difficulties, but through actively participating they were able to open channels with the local governments. At an earlier stage, local government had strictly regulated private schools, and many had failed to obtain permits, or were in other ways in conflict with local government. Participation in the Network enabled them to demonstrate their value to government officials, and to participate in regular dialogue with education bureaux, as well as providing facilities for the Network to operate night schools and training for rural migrant workers. Private schools also learned to cooperate among themselves instead of competing, using the Network to identify unmet demand. Private labour companies also benefited, as they were able to establish valuable relationships with the labour and, social insurance bureaus, Academy of Social Sciences and UNESCO.

In some of the local governments with dense populations of migrant workers, sub-district offices joined the Network as a means of ensuring security and implementing policies around healthcare, family planning and investment environment improvements set by higher levels of government. Here they joined the network to help with migrant worker training at construction sites, integrating them into urban life and showing how to protect their own rights. The government officials of social insurance bureau also joined in this network as part of a pilot scheme for non-urban employers. Demands and the feedback of opinions from migrant workers were collected by researchers and updated policies and actions of government were shared with network members.

\subsection{Advocacy}

Advocacy has been an important feature of the Network in action from the outset, when researchers and scholars highlighted the problems facing rural migrant workers, particularly women. Dialogue meetings are held with local government officials and there is much discussion of non-discriminatory service provision and the need to move from regulations and control to a service perspective. Here, media have been important partners of the Network. Network members believe that the attitudes of local Chengdu residents and grass roots 
government officials have a big influence on the social and cultural environment and can promote or restrict the integration of migrant workers into urban life. However, they also realised that these attitudes may not necessarily change in accordance with government policy. To address social exclusionary attitudes among the permanent Chengdu population, the Confidant magazine attached to Sichuan Women's Federation created a series of advertisements along the lines of: 'residents and villagers, we all are citizens', and 'working in city: longing for equal treatment without discrimination', to advocate equal rights for migrant workers.

In 2004, when private schools deemed unsafe were forcibly demolished, migrant children were left without classes to attend at the start of the new semester. Some were photographed standing in front of the debris, and the Sichuan Daily Press, a Network member, invited one of the network programme organisers, the Sichuan Academy of Social Sciences, as well as relevant government officials, lawyers, representatives of rural migrants and their children, and directors of both public and private migrant children schools to join in a dialogue. ${ }^{7}$ At the meeting, Network members engaged in heated debates with educational government officials. Local education bureau representatives argued that 'children's safety is more important than education service delivery', while Network representatives argued that rights to compulsory education in urban areas merited priority. Although neither party changed its opinions, one direct result was that Chengdu Education Bureau director and officials visited the Sichuan Academy of Social Sciences to ask their opinions and suggestions on resolving the question of compulsory education provision for rural migrant children in urban areas.

Local media not only supported rural migrant workers' rights publicly, some correspondent members of the Network also called for support for migrants directly in 'internal reference' reports distributed to local government departments. Correspondent members of the Sichuan Daily Press and Chengdu Business Daily regularly participated in activities organised by the Network. They organised visits by rural migrant children to museums and helped children left behind in villages to visit their parents in urban Chengdu. They also wrote and published more than 25 reports and commentaries advocating migrant workers' rights in other leading newspapers and periodicals, as well as reporting the situation and developing proposals in reports to local government.

In addition to intense print media activity, the support network handed out rights protection information leaflets during the Spring Festival in places such as Jiuyanqiao Labour Market, Huangwajie Labour Market and Hehuachi Commodity Market, where migrant workers worked and gathered. One Network member, Jintang County Women's Association, edited and handed out 'Migrant Workers' Mailbox', a newsletter for rural migrants covering information of relevance to migrant workers.

\subsection{Training as action}

In the early stages of the Network's activities, local civil society organisations had been invited to research rural migrant workers' livelihood and training demands in Chengdu. The results led those involved to give up plans to train local community and grass roots government officials in how to support rural migrant workers and, instead, to focus attention on strengthening the capacities of migrant workers themselves to survive and adapt in the urban setting. They adopted participatory methods and trained volunteer trainers from among rural migrant worker activists, from local colleges, officials of the Women's Association and researchers from the Academy of Social Sciences. The training focused on migrant workers' urban life, employment and career development and labour rights. Training on legal matters was organised with the West Xinhua Sub-district Public Office and skilled lawyers helped mainly construction workers not only to understand the environment of law and rights, but also to defend their own rights when necessary. In a similar way, the network held training courses on 'living in the city' to help rural migrants understand aspects of urban city life, such as the traffic system, banking system and the community service system. The support network also provided training on children's education to help parent's voice their requirements at migrant children schools. At Jintang County, the training also involved developing video programmes to be shown on the long-distance buses that transported workers to their migration destination places. 


\subsection{Women and children}

Special attention was paid to women and children. As a major organiser of the programme, the Sichuan Women's Association was particularly concerned about the rights of female migrant workers and was very active in social intervention and capacity building. The Confidant magazine press set up a 'Female Migrant Workers Hotline' and recruited voluntary hotline consultants - from college teachers and social workers - to offer counselling on psychology and rights protection, and organised a lawyer to give them legal aid.

In relation to children, besides the advocacy in relation to primary education, university student and social worker volunteers were organised to work in migrant children's schools and organise weekly activities for rural migrant children. In those private migrant schools in need of qualified teachers and equipment, or without laboratory classrooms and sports playgrounds, the volunteers organised visits to universities, museums, and provided extra curricular activities in English, dancing and sports. Volunteers also worked with the children left behind in the rural villages, helping them write to their parents as well as cooperating with local rural governments.

These activities led to a reappraisal by local governments of their own methods. As network members and partners, the Chengdu Women's Association and the Communist Youth League School adopted the methods in the migrant workers night school project funded by Chengdu Municipal Government.

\section{Conclusions}

Rural migrant workers in urban China suffer from a major accountability failure: their labour substantially drives urban-centred growth, but the dual administration systems means they have few rights or spaces in which to participate in urban local governance or the delivery of services that they need. This accountability failure has created a space in which 'civil society' organisations have flourished, even while facing a strong and everpresent state. Because local governments lack full responsibility for rural migrant workers, migrants lack formal and institutionalised channels to articulate their own concerns.

In this case, we have seen how two strategies for local civil society to participate in fighting against poverty and exclusion have complemented each other. On the one side is the work of civil society together with government and on the other is the cooperation with the private sector. Government has been important not only for revising the institutional system of regulations, policies for rural migrants in urban areas, but also in mobilising and allocating resources for labour rights protection, vocational training, primary education, health and medical care, living conditions. But local policy implementation is not always very successful; migrant workers' concerns are forced to compete with a wide range of other problems and tasks facing local governments.

In this case, as the organisers, Sichuan Women's Association and Sichuan Academy of Social Sciences have a background in government, they can conveniently organise and mobilise government partners and officials and local media into the Network. This cannot be achieved by NGOs or private companies with a pure 'civil society' identity. This social support network connects government with disadvantaged people, with the private service providing sector, and with NGOs and individuals working in this area. Such connections cannot be achieved by a government department because of the conflicts between the actors. The Support Network operates in effect as a social intermediary that buffers conflicts between local governments, rural migrants, civil society organisations and private companies; brings bilateral dialogue and communication; and may have the potential to provide some public services.

In brief, this case has demonstrated how civil society organisations can participate to combat poverty and exclusion against rural migrant workers in a situation in which power and resources are centralised, in which NGOs are historically weak, and in which there is a limited history and culture of civil society participation. 


\section{Notes}

1 www.gov.cn/zwgk/2005-08/12/content 21839.htm

2 www.gov.cn/jrzg/2006-03/27/content 237644.htm

3 See Zhan (2005) and UNESCO (2007) for background on migration policies and the UNESCO project Together with Migrants, of which Chengdu was part.

4 Sichuan Statistic Annual 2008. By the end of 2007, Sichuan had a population of 88 million, among which 67 were in rural villages.

\section{References}

Huang, Ping (2004) Together with Migrants: Urban Poor Among Young Migrants in China, Beijing: UNESCO

Merklen, Dennis (2007) Together with Migrants: A Qualitative Assessment of UNESCO's Project Urban Poverty Reduction Among Young and Female Migrants in China (2002-2007), Beijing: UNESCO

Ravallion, Martin and Shaohua, Chen (2004) Learning from Success: Understanding China's (Uneven) Progress Against Poverty, Washington DC: World Bank
5 http://unn.people.com.cn/GB/14748/ 8241373.html

6 Thomas Heberer (2005) 'Do Western Civil Society Values fit China', Nankai Journal 2, Philosophy, Literature and Social Science Edition, Nanjing.

7 www.scol.com.cn/nsichuan/sczh/20040906/ 20049612713.htm

UNESCO (2007) Together with Migrants: 2002-2007. Research and Action Against Poverty in China, Beijing: UNESCO

Yu, Keping (2009) Democracy is a Good Thing: Essays on Politics, Society, and Culture in Contemporary China, Washington DC: Brookings Institution Press

Zhan, Shaohua (2005) Rural Labour Migration in China: Challenges for Policies, Policy Paper 10, Paris: UNESCO 